\title{
KRITIKA BROWNOVEJ KONCEPCIE NENÁVISTNÉHO PREJAVU
}

MARIAN KUNA, Katedra filozofie, Filozofická fakulta Katolíckej univerzity v Ružomberku, Ružomberok, SR

KUNA, M.: A Critique of Brown's Concept of Hate Speech
FILOZOFIA, 75, 2020, No 2, pp. $77-90$

\begin{abstract}
This paper presents and evaluates Brown's analysis of the concept of hate speech. His analysis is seen as a valuable contribution to the discussion about the adequate definition of the term hate speech as an ordinary concept, which Brown understands as an equivocal idiom and family resemblance concept. However, as far as the concept of hate speech as a legal term is concerned and especially when the possible impact of Brown's conception on the legal regulation of hate speech is taken into account it suggests that Brown's approach appears problematic. Indeed, in the sphere of legal (especially criminal) regulation of hate speech the rule of law requires to respect the principle of legal certainty, i.e. to make every effort to define the term hate speech as a legal concept as univocally as possible. This is due to the fact that criminal regulation of hate speech poses potentially a serious threat to freedom of expression as a fundamental right of democratic citizenship.
\end{abstract}

Keywords: Alexander Brown - Freedom of speech - Hate speech - Hate speech law

\section{Úvod}

Potrebu filozofickej reflexie fenoménu nenávistného prejavu (hate speech) dnes asi netreba osobitne zdôvodňovat. ${ }^{1}$ Zdá sa, že verejné prejavy nenávisti sú na vzostupe, čo významná čast' spoločnosti vníma ako negatívny jav, ktorý si vyžaduje čoraz intenzívnejšiu právnu (najmä trestnoprávnu) reguláciu. ${ }^{2}$ Politici a právni teoretici sa preto musia vysporiadat's otázkou adekvátnej právnej regulácie nenávistných prejavov. V európskom kontexte ich reakcia do vel'kej miery predurčená existujúcimi medzinárodnoprávnymi záväzkami štátu (Steuer 2017). Klasickou európskou l'udskoprávnou reakciou je určitá forma trestnoprávnej represie rôznych podôb nenávistného prejavu

${ }^{1}$ Vel'ké množstvo anglojazyčnej filozofickej literatúry k tejto téme, napr. Brown (2015, 2017a, 2017b), Heinze (2016), Waldron (2012) a iní, je toho jednoznačným dôkazom.

${ }^{2}$ Príkladom je takzvaná protiextrémistická novela (respektíve sprísnenie a rozšírenie palety extrémistických trestných činov slovenského Trestného zákona z roku 2016. Viac pozri Steuer (2017, $484-488)$. 
(Kuna 2018; 2019). V tejto súvislosti však nemožno ignorovat' otázku účinnosti, ale aj politickej legitimity tejto regulácie, osobitne vzhladom na jej možné negatívne dôsledky na slobodu prejavu ako základnú politickú slobodu demokratického občianstva (Heinze 2015).

Neprekvapuje potom, že právni teoretici a filozofi skúmajú otázky povahy, respektíve jednotlivých variácíi legislatívy regulujúcej nenávistný prejav (hate speech laws). Išlo napríklad o otázky podobností a odlišností (Brown 2015), ale i legitimity, respektíve zdôvodnenia právneho obmedzovania nenávistných prejavov (hate speech bans) (napríklad Heinze 2015; Waldron 2012). Filozofi však (v kontexte súčasnej anglojazyčnej právnej filozofie) relatívne málo pozornosti venovali problematike pojmového vymedzenia termínu nenávistný prejav. Súčasne ho jednotliví autori chápu odlišne a jeho významovú rozmanitost' nevnímajú ako zásadný problém. Zdá sa však, že to problém je. Ako môže byt' diskusia na tému legitimity právneho obmedzovania nenávistného prejavu teoreticky adekvátna, ked' diskutujúci venujú vymedzeniu tohto klúčového termínu len okrajovú pozornost? Je totiž otázne, či možno presvedčivo skúmat' adekvátnu právnu (a mimoprávnu) reakciu na nenávistný prejav bez toho, aby sme disponovali dostatočne určitým (kontrolovatel’ným) významom tohto pojmu. ${ }^{3}$

Pojmové vymedzenie termínu nenávistný prejav považujeme za klúčcové pre adekvátnu diskusiu o regulácii tohto javu a tejto téme sa venuje i náš text. V prvej časti uvedieme kontextuálno-terminologické aspekty súčasného používania výrazu nenávistný prejav; $\mathrm{v}$ druhej časti predstavíme Brownovu originálnu koncepciu vymedzenia pojmu nenávistný prejav. $\mathrm{V}$ tretej časti kriticky hodnotíme prínos a limity Brownovho prístupu. Jeho prístup vnímame ako výrazný príspevok do diskusie o adekvátnom vymedzení termínu nenávistný prejav ako bežného (ordinary) pojmu. Pokial' však ide o jeho vymedzenie ako termínu právneho, máme výhrady k niektorým explicitným či implicitným implikáciám jeho koncepcie. Tvrdíme totiž, že do tej miery, do akej termín nenávistný prejav chápeme ako právny pojem, musíme ho vymedzit čo najjednoznačnejšie. Vyplýva to z povahy právnej, osobitne trestnoprávnej regulácie nenávistných prejavov, ked’že táto regulácia nevyhnutne generuje potenciálne závažné riziká pre naše demokratické právo na slobodu prejavu.

\section{Pojem nenávistný prejav - kontextuálna (nielen) terminologická poznámka}

V oblasti právneho (ako aj mimoprávneho) vymedzenia neexistuje jednotné chápanie významu termínu nenávistný prejav. A hoci v oblasti práva tento termín nemá presný

\footnotetext{
${ }^{3}$ Sám Ústavný súd Slovenskej republiky pri posudzovaní ústavnosti niektorých ustanovení takzvanej protiextrémistickej novely z roku 2016 v náleze PL. ÚS 5/2017 z 9. januára 2019 (d’alej 5/2017) konštatoval, že toto posúdenie nie je možné „bez uvažovania o nenávistnom prejave ako takom“ $(5 / 2017, \S 72)$.
} 
legálny význam, respektíve $\mathrm{v}$ medzinárodnom práve, ktoré sa týka l'udských práv, neexistuje jeho všeobecne prijímané chápanie, tento termín významne ovplyvňuje právo (Scruton 2007, 289). Jeho významová nejednotnost' (neurčitost' a nejednoznačnost') súvisí podl'a niektorých s tým, že konkrétne chápanie jeho významu je často odpoved'ou na ,špecifické a devastujúco diskriminačné sociálne javy či incidenty“ ('Hate Speech' 2009, 9). Z pohl'adu práva je však významová neurčitost' tohto pojmu nesporne nedostatkom $\mathrm{z}$ hl'adiska právnej istoty, osobitne $\mathrm{v}$ trestnoprávnom kontexte. Ak totiž neexistujú jeho všeobecne prijímané znaky, komplikuje to jednoznačné určenie, či niektorý prejav ešte nie je, alebo už je nenávistným prejavom, pričom tento problém nevyriešil ani Európsky súd pre l’udské práva v Štrasburgu (d’alej ESL'P), hoci s týmto pojmom štandardne pracuje (Steuer 2017, 477).

V súvislosti s používaním termínu nenávistný prejav v našich kultúrno-sociálnych a právnych reáliách treba poznamenat', že hoci v našom verejnom diskurze možno čoraz častejšie počut' výraz nenávistné prejavy, v Čechách a na Slovensku sú zaužívané skôr variácie výrazu extrémizmus, respektíve extrémistické prejavy (Černý 2008, Willfling 2017). V Európskej únii sa zasa používajú najmä pojmy rasizmus a xenofóbia (Ivor, Klimek, Záhora 2013, 363). Táto právna terminológia sa týka právnej (najmä trestnoprávnej) regulácie nenávistného prejavu. Pri nej je demokratický právny štát povinný rešpektovat' významný trestnoprávny princíp nihil crimen sine lege certa, ${ }^{4}$ ktorý je nevyhnutným korektívom skutočnosti, že „trestné právo má $\mathrm{k}$ dispozícii najprísnejšie prostriedky - tresty, a preto by malo byt' použité ako posledná a najkrajnejšia možnost' (ultima ratio)“ (Mencerová 2015, 17, 21). Preto je kl'účové čo najpresnejšie vymedzit' tento pojem tak, aby bol adekvátnym nástrojom na účely textácie príslušných trestnoprávnych ustanovení, ${ }^{5}$ ako aj ich následnej aplikácie zo strany súdov.

V oblasti tvorby, a najmä aplikácie práva, samozrejme existujú zaužívané spôsoby adekvátnej interpretácie právnych, osobitne neurčitých právnych pojmov. Táto interpretácia sa opiera o všeobecne akceptované závery právnej vedy a judikatúry. ${ }^{6}$

\footnotetext{
${ }^{4} \mathrm{~V}$ trestnom práve je ,zmyslom... vysokých nárokov na konzistenciu... maximalizácia právnej bezpečnosti obžalovaných vzhl’adom na vel'mi závažné dôsledky odsúdenia v trestnom konaní... [a tak] ... aplikácia takpovediac uzavretého predpisu, akým je Trestný zákon, je vel'mi analytická, postavená na význame každého jedného slova“" $(5 / 2017, \S \S 93,94)$.

${ }^{5}$ Ústavný súd SR akcentoval dôležitost' kvality (presnosti a určitosti) právneho textu, ako požiadavky princípu legality $(5 / 2017, \S 98)$. V súlade s tým pri uplatnení princípu opatrnosti v kontexte (posudzovania ústavnosti vybraných aspektov) nenávistných trestných činov konštatoval, že „nemôže nechat' práve právnu úpravu trestného práva hmotného - verbálnych trestných činov testovat' praxou, teda tým, či bude judikatúra správne vykladat' otvorenú klauzulu. Hlavne policajné autority, ale aj ostatné orgány činné v trestnom konaní potrebujú mat' pri tomto type trestnej činnosti zretel'né kontúry pravidiel $(5 / 2017, \S 102)$.

${ }^{6}$ Význam judikatúry pre interpretáciu práva kontinentálnej právnej kultúre a v právnej tradícii common law výstižne približujú Bobek a Kühn (2013, 15 - 74). Viac k povahe právnej interpretácie pozri Gahér (2015a; 2015b).
} 
To platí pre vymedzenie a interpretáciu dôležitých trestnoprávnych termínov. V právnej interpretácii tak určitý termín môžeme chápat' bud' ako pojem jednoznačný, alebo mnohoznačný, pričom v prvom prípade bude relatívne jednoduché zistit' autoritatívny (respektíve právne záväzný) význam daného termínu. Ak však pôjde o viacvýznamový termín, situácia bude zložitejšia, ked'že budeme musiet' identifikovat' jeho verejno-mocensky akceptované významy z relevantných autoritatívnych rozhodnutí súdov. Ak však pre istý klúčový právny termín neexistuje dostatočná judikatúra, alebo je vzájomne protirečivá, a v prípade, že svetlo do veci nevnesie ani príslušná dôvodová správa $\mathrm{k}$ zákonu, zdá sa, že jediným riešením bude usilovat' sa vytvorit' kompetentnú právno-teoretickú pozíciu k skúmanej otázke. Veríme, že kritické zhodnotenie Brownovej koncepcie môže byt' v tomto smere prínosom.

\section{Brownova koncepcia významu pojmu nenávistný prejav}

Brown chce adekvátne vymedzit' pojem nenávistný prejav, a to prostredníctvom metód pojmovej analýzy analytickej filozofie. Nejde mu primárne o jeho vymedzenie ako právneho termínu, ale ako bežného (ordinary) termínu. Ide mu najmä o diskreditáciu relatívne rozšírenej predstavy (takzvaného mýtu nenávisti), že „emócie, pocity či postoje nenávisti tvoria súčast' esenciálnej povahy nenávistného prejavu. ... [a obhajobu jeho presvedčenia, že] ... nenávistný prejav je najvhodnejšie chápat' ako rodinne podobný pojem (a family resemblance concept)“ (2017a, 419). V tejto časti načrtneme Brownove argumenty v prospech týchto jeho tvrdení. Najprv poukážeme na právny kontext diskusie o nenávistnom prejave, všimneme si nenávistný prejav ako právny, a následne ako bežný, respektíve rodinne podobný pojem.

\subsection{Právny kontext diskusie o nenávistnom prejave}

V diskusii o legitimite nenávistného prejavu v demokratickej spoločnosti jej účastníci vždy pracujú s určitým predporozumením, prípadne tou či onou definíciou nenávistného prejavu. Ak vychádzame $\mathrm{z}$ toho, že $\mathrm{v}$ centre tejto diskusie je právne obmedzovanie nenávistných prejavov, neprekvapí nás, že právni teoretici vypracovali celý rad definícií nenávistného prejavu ako právneho pojmu, čo úzko súvisí s tým, že tieto definície sú (v zmysle pozícií právnej vedy ako prameňa doktrinálnej právnej interpretácie) dôležitým nástrojom právnej regulácie tohto fenoménu. Tieto definície sa nielen líšia, ale sú často vo vzájomnom priamom protiklade, a tak je definovanie pojmu nenávistný prejav predmetom zásadnej nezhody (Brown 2017a, 421 - 422).

Avšak na to, aby sme mohli adekvátne (právne či mimoprávne) reagovat' na fenomén nenávistného prejavu, musíme najprv adekvátne reflektovat' skutočnost', že nenávistný prejav nie je výlučne právny pojem (teda v úzkom zmysle slova), ale ide aj o všeobecne používaný, respektíve bežný (ordinary) pojem, teda pojem v širokom 
zmysle slova. Brown pokladá za dôležité zamerat' sa na preskúmanie jeho bežného významu prostredníctvom metód filozofickej pojmovej analýzy, pričom zdôrazňuje nutnost' odmietnut' isté implicitné predpoklady, ktoré filozofi preberajú od právnych teoretikov, a zároveň na rozdiel od právnych teoretikov tvrdí, že „nenávistný prejav“ je rodinne podobný pojem, a preto neumožňuje, aby sme ho definovali (2017a, 422 - 423).

V súvislosti s rozdielom medzi bežným a právnym významom pojmu nenávistný prejav Brown poznamenáva, že jeho právne vymedzenie je len „špičkou l'adovca“ skutočnosti, ktorá predstavuje „nespočítatel’ne rozličné typy kontextov, týkajúce sa nesmiernej rozmanitosti tohto fenoménu“ (2017a, 424). A tak hoci historicky má termín nenávistný prejav svoje korene v reakciách na zlyhania právneho systému v súvislosti s právnou ochranou a nápravami škôd spôsobených obetiam nenávistne motivovaných trestných činov, médiá a sociálne siete významne prispeli k výraznému rozšíreniu jeho používania aj medzi l'ud'mi, ktorí sami nie sú právnikmi. Toto rozšírenie sa navyše odohráva v rozličných mimoprávnych kontextoch vrátane populárnej kultúry (2017a, $424-426)$.

Zároveň je dôležité uvedomit’ si, že filozofi skúmajúci otázky, ktoré sa týkajú nenávistného prejavu, sú do výraznej miery ovplyvnení teoretickými reflexiami tohto javu, ktoré vypracovali právni teoretici . Načrtnutý vzt’ah právneho a bežného významu termínu nenávistný prejav je vzájomne obohacujúci, ale súčasne problematický. Problematický je najmä vtedy, ked’ filozofi od právnikov (nedostatočne kriticky) preberajú predstavu, že emócie a postoje nenávisti sú esenciálnou súčast’ou podstaty nenávistného prejavu (mýtus nenávisti) - teda predstavu, že prítomnost' nenávisti v prejave ho odlišuje od iných typov prejavu. ${ }^{7}$ Problematická je aj predstava, že ide o zložený termín, ktorý je jednoznačný a definovatel'ný, teda že má jeden význam (čo Brown označuje za mýtus zloženosti). Obe predstavy Brown podrobuje zásadnej kritike (2017a, 430 - 433).

\subsection{Nenávistný prejav ako právny pojem}

Na právne chápanie nenávistného prejavu Brown aplikuje metódu pojmovej právnej vedy (conceptual jurisprudence), teda všíma si jeho pozitívne a negatívne vymedzenia v právnych textoch a právnej praxi (vrátane jemu významovo príbuzných termínov) vnútroštátnej a medzinárodnoprávnej povahy. Práce právnych vedcov a lexikografov podla neho poukazujú na momenty zhody, ako aj na významnú mieru nekonzistentnosti a protirečivosti pri snahe zmapovat' existujúce použitia

\footnotetext{
${ }^{7}$ Zdá sa, že aj Ústavný súd SR predpokladá prítomnost' nenávisti pri nenávistných činoch, ked' predstavuje pät' hierarchicky usporiadaných druhov „nenávistí“, a to na jednej strane od skutkov mimoprávnych až po skutky trestnoprávne a na druhej strane od skutkov, ktoré sú pokryté režimom slobody prejavu až po tie, ktoré sú mimo tohto režimu $(5 / 2017, \S 88)$.
} 
termínu nenávistný prejav v právnom kontexte. Tieto skúmania sa týkajú otázky spojenia prejavu a nenávisti, otázky identifikácie skupín pokrytých právnym termínom nenávistný prejav či povahy prejavu. Brown poukazuje na zásadné obmedzenia právno-lexikografického prístupu, ako aj jeho výsledkov, tkvejúce v tom, že jeho charakterizácie sú príliš reštriktívne a zároveň príliš extenzívne (2017a, 433, 436 - 438).

Táto reštriktívnost' a extenzívnost' však majú svoje vysvetlenie. Reštriktívne chápanie právneho termínu nenávistný prejav (napríklad v zmysle výrazu ,podnecovanie k nenávisti““) je užitočné v kontexte ochrany ústavného práva na slobodu prejavu, ktorú občanom garantuje demokratický právny štát. Avšak vo vzt’ahu k bežnému pojmu nenávistného prejavu ide o také jeho obmedzenie, ktoré nie je nevyhnutné. To má za následok, že právne chápanie tohto pojmu je nepresné a neužitočné, ak sa použije na jeho bežný význam. Uvedené právne chápanie je zároveň príliš extenzívne, ak je podmienkou toho, aby sme nejaký prejav označili za nenávistný to, že je spojený s emóciu nenávisti (čo je dôsledok mýtu nenávisti). Brown je presvedčený o tom, že správne pochopený termín nenávistný prejav je s emóciou nenávisti spojený nanajvýš kontingentne. Ide o to, že autor takéhoto prejavu môže byt' motivovaný celým radom iných motivácií, ktoré sú odlišné od nenávisti, ako napríklad úzkost'ou či znechutením (2017a, 439-441).

\subsection{Nenávistný prejav ako bežný (ordinary) pojem}

Brown sa usiluje preukázat', že nenávistný prejav ako bežný pojem nie je zložený pojem, ktorého adekvátny význam by bol poznatel'ný metódou dekompozičnej pojmovej analýzy. ${ }^{8}$ Keby bol „nenávistný prejav“ zloženým pojmom, jeho význam by bol funkciou významu pojmových častí, z ktorých pozostáva, teda významu výrazov prejav a nenávist'. Avšak tento pojem je zložitejší, ako len spojenie týchto dvoch výrazov, nakol'ko v sebe zahŕňa aj pojem skupiny osôb (napríklad historicky utláčanej či marginalizovanej skupiny), ktorá je identifikovaná určitými uznanými chránenými charakteristikami (ako sú najmä rasa, náboženstvo, pôvod, sociálne postavenie, pohlavie a pod.). Vzhl'adom na povahu, respektíve rozmanitost' týchto chránených charakteristík a ich odlišné zoznamy u jednotlivých autorov, ktoré sú skôr demonštratívne ako taxatívne, čelíme problému adekvátnej definície nenávistného prejavu (2017a, 442 - 445).

Brown však preskúmava aj dôsledky predpokladu, že by sme nenávistný prejav chápali ako kompozičný pojem. Takýto pojem by potom pozostával z troch nasledujúcich prvkov: 1) prejav; 2) skupina osôb identifikovaná chránenými charakteristikami a 3) emócia nenávisti. Osobitne analyzuje práve tretí prvok, či skôr spôsob,

\footnotetext{
${ }^{8}$ Táto metóda definuje pojem tým, že delí zložený pojem na menšie časti, z ktorých tento pozostáva, a umožňuje presné definície pojmov tým, že špecifikuje súbor nevyhnutných a postačujúcich podmienok na správne použitie tohto pojmu (Brown 2017a, 24).
} 
akým má byt' takýto prejav (negatívne orientovaný na uvedenú skupinu osôb) spojený s emóciou nenávisti. Identifikuje štyri možné formy ich spojenia a tvrdí, že zakaždým ide o výlučne kontingentné spojenie. Tvrdí, že mýtus nenávisti je neudržatel'ný, ked’že poukazuje aj na rozmanité prípady nenávistného prejavu, v ktorých emócia nenávisti absentuje (2017a, 446, 447, 449, 455, 458, 461).

Brown spochybňuje predpoklad, že „, termíne ,nenávistný prejav‘ výraz ,nenávist" funguje sémanticky rovnakým spôsobom ako v prípade iných zložených pojmov (ako napríklad hate crime), ktoré tento výraz obsahujú“ (2017a, 461). V mnohých prípadoch nenávistného prejavu je totiž ich spojenie s emóciou nenávisti bud’ slabé, alebo nijaké (2017a, 466). Ide o to, že „niektoré prípady nenávistného prejavu nemajú nič spoločné s nenávist'ou v striktnom zmysle slova, ale majú vel’a spoločného s emóciami, pocitmi či postojmi opovrhnutia, pohŕdania, odporu, povýšenosti alebo odmietania, čo je vecou vnímania niečoho alebo niekoho ako takého, ktorý je nehodný našej pozornosti, a nutkania či dôvodu, aby sme od tejto veci či osoby mali odstup, vyhli sa jej, alebo od nej bočili““ (2017a, 440).

\subsection{Nenávistný prejav ako rodinne podobný (family resemblance) pojem}

Brown tvrdí, že pojem nenávistný prejav nie je zložený a jednoznačný pojem, ale je prípadom mnohoznačného idiómu, „ktorý označuje rodinu významov, pre ktoré neexistuje nijaká jedna zastrešujúca a presná definícia“ (2017b, 562). Teda tvrdí, že tento termín je prípadom toho, čo Ludwig Wittgenstein identifikoval a pomenoval ako rodinne podobný pojem (Wittgenstein 1979, § 67, s. 56). ${ }^{9}$ Jeho mnohoznačnost' sa vyjavuje v tom, že ,je aplikovatel'ný na nespočetné variácie relatívne neobmedzených typov kontextu, obsahu prejavu, emócií, pocitov či postojov hovoriaceho a typov činnosti.... [Tento] pojem je systematicky nejednoznačný ... [resp.] ... nesie mnohorakost' odlišných významov“ (Brown 2017b, $563-564$ ). ${ }^{10}$

Brown podrobuje pojem nenávistný prejav štyrom metódam pojmovej analýzy, ktorých aplikovaním dospieva k zisteniam, že: 1) nedospejeme $\mathrm{k}$ jednotnej definícii nenávistného prejavu, ale skôr k rodine vzájomne odlišných významov pojmu, ktoré reflektujú pluralitu účelov jeho použitia; 2) zaužívané frázy, ktoré sa týkajú pojmu nenávistný prejav, vyžadujú fillozofickú kritiku na to, aby sám pojem plnil svoju úlohu, a na to, aby sme ho v úmysle ochrany slobody prejavu nechápali príliš úzko v zmysle právne regulovatel'ného správania; 3) existuje (minimálne) pät' širokých, navzájom sa nevylučujúcich typov nenávistného prejavu, pričom nemajú určitú

${ }^{9}$ Stratégia definovania pojmov cez koncepciu rodinných podobností (Familienähnlichkeiten) sa stala známou v 20. storočí vd’aka Filozofickým skúmaniam Ludwiga Wittgensteina (1979, § 67, s. 56). Ich využitie možno badat' v širokom spektre oblastí teoretického výskumu, napr. Hrkút (2018).

${ }_{10}$ Witgensteinovu koncepciu výstižne explikoval Labuda v kontexte obhajoby idey, že filozofiu treba chápat' zásadne ako aktivitu $(2018,367$ - 368). 
spoločnú kvalitu nad rámec toho, že sú typicky intuitívne vnímané ako prípady nenávistného prejavu; 4) používatelia prirodzeného jazyka neidentifikujú prípady nenávistného prejavu výlučne pozornost'ou $\mathrm{k}$ určitým použitým slovám, ale tiež vnímaním toho, čo ludia svojimi slovami konajú (2017b, 562, 566, 573, 580, 583, 590).

To podl'a Browna preukazuje, že nenávistný prejav je rodinne podobný pojem, pri ktorom „niekto môže byt' kompetentný používatel' relevantného pojmu aj vtedy, ak nedokáže artikulovat' presnú definíciu tohto pojmu (v zmysle súboru nevyhnutných a spoločne postačujúcich podmienok jeho správneho použitia), pretože tento pojem takúto definíciu neumožňuje. ${ }^{11} \mathrm{Na}$ čom skutočne záleží, je to, že niekto vie, ako byt' účastníkom spoločnej činnosti používania tohto pojmu“ (2017b, 593). Pri tomto pojme nejde len o to, že termín ako taký je $\mathrm{v}$ priebehu času používaný nepredvídaným spôsobom (teda nevieme vopred vymenovat' všetky jeho legitímne použitia), ale aj o to, že jeho analytickú definíciu vlastne ani nepotrebujeme. Je to preto, lebo ak ho chápeme ako rodinne podobný pojem, vieme, že jednotlivé prípady nenávistného prejavu spájajú určité vlastnosti (teda každý prípad má aspoň jednu podobnú kvalitu $\mathrm{s}$ inou v danej skupine), z ktorých nijaká nie je spoločná všetkým jednotlivým prípadom (2017b, 595 - 596).

Brown zdôrazňuje, že ked’ tvrdí, že pojem „nenávistný prejav“ je rodinne podobný pojem, ide mu primárne o jeho bežný (ordinary) význam, a nie o jeho právny význam. Teda nejde mu o jeho použitie ako právno-technického výrazu, kde sa vyžaduje jeho presná, a teda i úzka definícia, ktorá je dostatočne jednoznačná na to, aby bola použitelná v súdnom konaní. Určité špecifikum však podl’a neho tvoria nástroje medzinárodnej l’udskoprávnej ochrany, ktoré používajú právnu terminológiu abstraktnejšej povahy, a zároveň určité rámcové pojmy (respektíve špecifické právne termíny ako napríklad výraz podnecovanie k nenávisti) interpretujú v porovnaní s vnútroštátnou právnou úpravou extenzívnejším spôsobom (2017b, 602 - 603).

\section{Prínos a limity Brownovej koncepcie nenávistného prejavu}

Za najdôležitejšie výsledky Brownovej analýzy termínu nenávistný prejav ako bežného pojmu na účely reflexie fenoménu nenávistného prejavu pokladáme jeho nasledujúce dve zistenia. Po prvé, zdá sa, že Brown preukázal, že tento termín ako bežný pojem nie je jednoznačný ani zložený pojem, ale je prípadom mnohoznačného a rodinne podobného pojmu. Po druhé, zdá sa, že poukázal na dôležité skutočnosti, ktoré nasvedčujú tomu, že tento termín nie je spojený s emóciou nenávisti nevyhnutne, ale len kontingentne, respektíve že nenávist' nie je jeho esenciálnou vlastnost'ou. Brown

${ }^{11}$ Kontrolu nad správnym používaním pojmu zabezpečuje účastníkovi používania rodinne podobného pojmu to, že disponuje takzvanými účastníckymi znalost'ami (participatory knowledge), ktoré „bránia tomu, aby používanie daného termínu upadlo do nekoherentosti“ (Brown 2017b, 596). 
však formuluje aj viacero súvisiacich tvrdení, ktoré majú závažné implikácie, a preto si zasluhujú kritické preskúmanie.

Ide najmä o isté implikácie jeho koncepcie nenávistného prejavu ako bežného pojmu pre chápanie termínu nenávistný prejav v jeho právnom význame. Ide o jeho chápanie $\mathrm{v}$ užšom právnom (respektíve medzinárodnoprávnom) a širšom právnom význame (vnútroštátnom či trestnoprávnom) význame. Domnievame sa, že hoci Brownov prístup predstavuje filozoficky cenný príspevok $\mathrm{k}$ adekvátnemu porozumeniu termínu nenávistný prejav v jeho bežnom význame, má určité problematické, ba až potenciálne nebezpečné implikácie, ak je aplikovaný v kontexte právnej ochrany slobody prejavu $\mathrm{v}$ jeho užšom, a $\mathrm{v}$ tejto súvislosti nevyhnutne aj $\mathrm{v}$ širšom právnom význame. Avšak ešte predtým, ako si ich bližšie všimneme a navrhneme korektúru Brownovej koncepcie v kontexte právnej regulácie nenávistného prejavu, pokladáme za vhodné všimnút' si a komentovat' Brownov vlastný uhol pohl'adu na prínos jeho koncepcie pre diskusiu o nenávistnom prejave.

Po prvé, Brown pokladá za prínos svojho chápania bežného pojmu nenávistný prejav ako rodinne podobného pojmu to, že nás robí vnímavejšimi v rozpoznávaní výskytu nenávistných prejavov v porovnaní s tým, čo nám umožňovala jeho (právnym kontextom používania termínu poznačená) klasická analytická definícia. Tým sa podl'a neho zvyšuje šanca, že nedôjde $\mathrm{k}$ negatívnym praktickým dôsledkom normalizácie nenávistných prejavov a $\mathrm{k}$ ich prehliadaniu, teda $\mathrm{k}$ javu, ktorý negatívne zasahuje ich adresátov (obete). Užitočnost' svojho chápania tohto pojmu vidí práve v tom, že „môže byt' diverzifikovaný tak, aby zahŕňal celý rad vecí, ktoré sa podobajú i nepodobajú na rasistické urážky a ktoré sa navzájom podobajú i nepodobajú. Sama skutočnost', že pojem nenávistný prejav označuje komplikovanú mozaiku navzájom sa prekrývajúcich a krížových podobností, z neho robí ovel'a flexibilnejší koncept ... [respektíve] ... ovel'a širší a potentnejší (more capacious) pojem“" (2017b, 604; 2017a, 428).

Zdá sa, že chápanie termínu nenávistný prejav $\mathrm{v}$ zmysle bežného pojmu ako pojmu jednoznačného a zloženého naozaj generuje výraznú, a súčasne nekonzistentnú heterogenitu chápaní jeho významu. Rovnako sa zdá, že ak budeme tento termín chápat' ako mnohoznačný idióm, alebo ako rodinne podobný pojem, tak sa uvedenému problému úspešne vyhneme, a zároveň získame ,ovel’a flexibilnejší koncept“. Výhody jeho aplikačnej flexibility sú však určitými výhodami nanajvýš v mimoprávnom kontexte (a aj tam nie vždy), ${ }^{12}$ teda ked' ide o termín $\mathrm{v}$ jeho bežnom, a nie $\mathrm{v}$ jeho právnom význame. A hoci obidva tieto významy Brown striktne oddeluje, uvedomuje si, že bežné chápanie pojmu nenávistný prejav môže ovplyvňovat' špecificky právnu interpretáciu tohto

${ }^{12}$ Treba si totiž uvedomit', že aj určitý primárne mimoprávny (napríklad akademický) kontext totiž môže byt' miestom nelegitímnej sociálnej represie slobody prejavu, osobitne v prípadoch extrémne extenzívneho chápania pojmu nenávistný prejav. 
pojmu. Platí to najmä vtedy, ak orgán interpretácie či aplikácie práva vo svojej rozhodovacej činnosti explicitne alebo implicitne zaujíma postoj, že právny význam pojmu treba zásadne interpretovat' $v$ súlade s jeho bežným (ordinary) významom, teda že jeho právny význam v zásade závisí od jeho mimoprávneho (!) významu (2017a, 429). Možných negatívnych dôsledkov tejto skutočnosti sa ešte dotkneme.

Po druhé, Brown považuje za prínos svojej diskvalifikácie chybnej predstavy o nevyhnutnom spojení emócie nenávisti s nenávistným prejavom to, že uvedené zistenie nás privádza na správny spôsob uvažovania o tomto fenoméne, ako aj na adekvátny spôsob komunikácie s verejnými autoritami v súvislosti s ich úlohami pri právnych (!) a mimoprávnych opatreniach, ktoré sa týkajú nenávistných prejavov (2017b, 605). Napriek ich vzájomnej historickej afinite Brown konštatuje, že termín nenávistný prejav sa ako právny a bežný pojem rozchádzajú, pričom tento trend nevníma negatívne. Tvrdí, že keby sme stotožnili význam tohto pojmu výlučne s jeho legálnou definíciou, verejná autorita by čelila dileme bud' trestnoprávne reagovat', alebo zaujat' postoj pasivity. ${ }^{13}$ Takto máme podla Browna $\mathrm{k}$ dispozícii rozmanité - právne a mimoprávne - spôsoby ako reagovat' na nenávistné prejavy, čo je v súlade s medzinárodnými l’udskoprávnymi odporúčaniami, ako aj s vývojom obmedzovania nenávistných prejavov zo strany prevádzkovatel'ov internetových platforiem a webových stránok $(2017 \mathrm{~b}, 609-612)$.

Aj v tomto prípade platí, že nemožno vylúčit to, že v tom či onom prípade nenávistného prejavu v bežnom (mimoprávnom) zmysle nie je takmer alebo vôbec prítomná emócia nenávisti, špecificky zameraná voči jednotlivcovi ako príslušníkovi určitej skupiny v zmysle určitej chránenej charakteristiky. Pre právnu reguláciu nenávistného prejavu v našom trestnoprávnom kontexte je však príznačná požiadavka, respektíve povinnost' preukazovat' prítomnost' diskriminačno-nenávistnej motivácie ako súčasti preukazovania úmyselnej formy zavinenia zo strany orgánu aplikácie práva, ked’že táto nenávistná motivácia je nevyhnutným predpokladom na vyvodenie trestnoprávnej zodpovednosti za typicky nenávistné (alebo extrémistické) trestné činy (Herczeg 2007, 29, 39). Brown by mohol namietat', že vo svojom prístupe striktne rozlišuje medzi používaním pojmu nenávistný prejav ako bežným pojmom na účely mimoprávnej reakcie na nenávistné prejavy a medzi jeho chápaním ako právnym pojmom na účely trestnoprávnej represie (2017a, 439).

K tomu však treba povedat', že sa zdá, že Brown minimálne čiastočne podl'ahol pokušeniu urobit' svoje chápanie termínu nenávistný prejav ako bežného pojmu

13 Táto dilema však podl'a nás stelesňuje parametre právneho štátu. Zároveň chceme vyzdvihnút' ideu Ústavného súdu SR o potrebe „uvažovat’ aj o subtílnejších formách reakcie na nenávist'. ... [poukazujúc na to, že] v niektorých krajinách sú tieto skutky v režime súkromnožalobných deliktov s účast'ou občianskych združení“ (5/2017, § 113). 
operatívnym nad rámec ním deklarovanej ambície obmedzit' sa na jeho bežné (mimoprávne) používanie. Robí to $\mathrm{v}$ momente, ked' svoje chápanie tohto termínu $\mathrm{v}$ bežnom zmysle ako rodinne podobného pojmu rozširuje aj na jeho použitia v kontexte medzinárodnoprávnej l’udskoprávnej regulácie nenávistných prejavov, konkrétne $\mathrm{v}$ rámci aplikácie práva (teda takzvaného Európskeho dohovoru) ${ }^{14}$ zo strany ESL'P. V tejto súvislosti je vskutku vel’avravné , že sám Brown vníma prístup ESL'P k prezentácii jeho chápania nenávistných prejavov ako užitočný a oceňuje na ňom práve to, že sa „nepokúša sformulovat' všeobecne prijímanú definíciu termínu nenávistný prejav, ale namiesto toho poukazuje na rôzne konvencie a celý rad právnych prípadov, ktoré sa podl'a jeho názoru týkajú nenávistných prejavov“ (2017a, 436). ${ }^{15}$

Ide o to, že Brown explicitne vyhlasuje, že jeho chápanie nenávistného prejavu ako bežného pojmu, teda pojmu pomerne flexibilného a systematicky viacznačného (rodinne podobného), je v zásade použitel’né aj v právnej oblasti, konkrétne v oblasti už spomenutých medzinárodnoprávnych nástrojov ochrany l’udských práv. Je pravda, že Brown zdôrazňuje, že sa to netýka špecifickejších a konkrétnejších právnych pojmov, používaných na účely súdneho konania $(2017 b, 603)$. No zdá sa, že toto jeho dementi je problematické. Ide o to, že $v$ tejto súvislosti treba brat vážne normatívne pôsobenie judikatúry ESL'P voči signatárskym štátom Európskeho dohovoru v ich vnútroštátnej legislatívnej úprave a aplikačnej praxi (Kuna 2018, 55). Inými slovami, je t’ažké vidiet', akým spôsobom sa v konečnom dôsledku možno vyhnút negatívnych dopadom ním vyzdvihovanej významovej „flexibility“ (či skôr nestability a vágnosti) prístupu ESL'P k nenávistným prejavom na vnútroštátnu trestnoprávnu reguláciu nenávistných prejavov. ${ }^{16}$

Treba si uvedomit', že judikatúra ESL'P, ktorá sa týka nenávistných prejavov, dnes čelí zásadnej kritike pre svoju nekonzistentnost' a s ňou spojenú nepredvídatel'nost' (Kiska 2012 - 2013). Načrtnutý Brownov postoj môže túto situáciu ešte zhoršit', preto sa nazdávame, že ho treba odmietnut' ako nelegitímnu a potenciálne nebezpečnú extenziu jeho záverov, ktoré súvisia s bežným významom termínu nenávistný prejav smerom $\mathrm{k}$ špecificky právnemu chápaniu tohto termínu. V tejto súvislosti treba, naopak, apelovat' na čo najdôslednejšie dodržiavanie princípov právneho štátu, respektíve princípu právnej istoty. ${ }^{17}$ Je zrejmé, že princíp právnej istoty porušuje viacznačná,

${ }^{14}$ Dohovor o ochrane l'udských práv a základných slobôd (Oznámenie č. 209/1992 Zb.).
${ }^{15}$ Nenávistné prejavy, ktoré neobsahujú výraz ,nenávist‘“, majú napríklad podobu výrazov: revizi-
onizmus a negacionizmus, obhajoba násilia a podnecovanie k nepriatel'stvu, schval'ovanie teroriz-
mu, ospravedlňovanie vojnových zločinov, znevažovanie národnej identity. Hate Speech 2017 .
${ }^{16}$ Bližšie k analýze a kritike týchto závažných nedostatkov v judikatúre ESL’P, ktorá sa týka nená-
vistných prejavov pozri Kiska ( 2012 - 2013).
${ }^{17}$ Je zrejmé, že právny štát musí rešpektovat’ aj iné princípy ako len princíp právnej istoty, a tak istá
miera flexibility právnych pojmov je nielen vhodná, ale dokonca nevyhnutná na dosahovanie účelu
právnej regulácie. Táto flexibilita je však limitovaná ústavnoprávnym princípom, že súdy pri 
nejasná či nestabilná legislatíva a judikatúra najmä tým, že robí právnu reguláciu nenávistného prejavu nepredvídatel'nou. ${ }^{18}$ Ide o zásadný problém, ktorého možné negatívne dôsledky však možno minimalizovat' len dôsledným uplatňovaním princípu, že l'udské práva (vrátane slobody prejavu) majú v demokratickom právnom štáte kl'účový interpretačný význam, pričom platí, že „,ked' zákon nie je jednoznačný, je vykladaný v prospech týchto práv (zásada in dubio pro libertate) “ (Gerloch 2013, 203). ${ }^{19}$

Navyše vzhl'adom na to, že bežné chápanie pojmu nenávistný prejav nakoniec aj tak tou či onou formou minimálne nepriamo ovplyvňuje právne chápanie pojmu nenávistný prejav, treba zaujat' postoj adekvátnej zdržanlivosti aj voči neprimerane flexibilnému používaniu termínu nenávistný prejav ako bežného pojmu. Ide o to, že hoci je trestnoprávne obmedzovanie slobody prejavu v prípadoch nenávistného prejavu najcitel'nejším zásahom do slobody prejavu jednotlivca, nijako to neumenšuje závažnost' možných neprimerane extenzívnych mimoprávnych foriem obmedzovania slobody prejavu. Ide o to, že nejasné a nepredvídatel'né, respektíve neprimerane extenzívne chápanie nenávistných prejavov, ktoré sú na základe tohto chápania následne obmedzované $\mathrm{v}$ rámci samoregulácie príslušného verejného fóra, môže viest' $\mathrm{k}$ nelegitímnemu, ba až škodlivému vplyvu na povahu verejnej, ale napríklad aj akademickej diskusie. $^{20}$

\section{Záver}

Možno konštatovat', že Brownov prístup je cenným príspevkom do diskusie o adekvátnom vymedzení termínu nenávistný prejav ako bežného pojmu tým, že ho vymedzuje ako mnohoznačný idióm či rodinne podobný pojem. Pokial' však ide o pojem nenávistný prejav ako špecificky právny pojem, alebo o možné presahy Brownovho (mimoprávneho) chápania pojmu do sféry jeho právnej regulácie, zdá sa, že jeho použitel'nost' je značne problematická a môže mat' negatívne dôsledky na slobodu prejavu. $\mathrm{Z}$ toho dôvodu si prípadná recepcia jeho koncepcie vyžaduje značnú ostražitost' nielen

\footnotetext{
obmedzovaní slobody prejavu musia dbat' na podstatu a zmysel slobody prejavu a súčasne musia jej legitímne obmedzenia aplikovat' rovnako na všetky relevantné prípady.

18 Ústavnoprávne sa nevyžaduje ,predvídatel'nost' založená na absolútnej a jednoduchej (až primitívnej) istote možného trestného postihu. ... [ale vyžaduje sa] ... taká formulácia skutkovej podstaty trestného činu, ktorá u bežného (priemerného) adresáta nevyvoláva pochybnost' o tom, čo je už zakázané pod sankciou trestného postihu“" $(5 / 2017, \S 98)$.

${ }^{19}$ Zdá sa, že práve takto postupoval aj Ústavný súd SR, ked' v kontexte prieskumu ústavnosti napadnutých častí ustanovení extrémistických trestných činov aplikoval princíp opatrnosti a konštatoval ich nesúlad s ústavou $(5 / 2017, \S 102)$.

${ }^{20}$ To, že nejde len o hypotetickú možnost', dokladá študentský pokus o vypudenie filozofa Johna Finnisa z Oxfordskej univerzity. Jeho názory niektorí študenti vyhodnotili ako nedostatočne politicky korektné, respektíve ako ideologicky závadné. Viac pozri Krivošík (2019) a ku kritickej reflexii ideologickej povahy tejto kauzy pozri Heinze (2019).
} 
zo strany občanov (a občianskej spoločnosti), ale najmä zo strany orgánov tvorby a aplikácie práva. Ide o to, že vo sfére medzinárodnej a vnútroštátnej právnej regulácie, osobitne v kontexte trestnoprávneho obmedzovania nenávistných prejavov, je v zmysle princípov právneho štátu, a to najmä princípu právnej istoty, nevyhnutné vyvinút' maximálne úsilie, aby sme termín nenávistný prejav (a s ním súvisiace právne pojmy) vymedzili tak jednoznačne, ako je to len možné. Znamená to, že k pojmu nenávistný prejav ako právnemu pojmu je vhodné pristupovat' tak, akoby šlo o pojem jednoznačný. Tento záver je odôvodnený povahou právnej, a najmä trestnoprávnej regulácie nenávistných prejavov - špecificky právnych ohrození, ktoré táto regulácia predstavuje pre slobodu prejavu ako základné právo demokratického občianstva.

\section{Literatúra}

BOBEK, M. - KÜHN, Z. a kol. (2013): Judikatura a právní argumentace. 2. vydání. Praha: Auditorium. BROWN, A. (2015): Hate Speech Law: A Philosophical Examination. New York - London: Routledge.

BROWN, A. (2017a): What Is Hate Speech? Part 1: The Myth of Hate. Law and Philosophy, 36 (4), 419 - 468. DOI: https://doi.org/10.1007/s10982-017-9297-1

BROWN, A. (2017b): What Is Hate Speech? Part 2: Family Resemblances. Law and Philosophy, 36, 561-613. DOI: https://doi.org/10.1007/s10982-017-9300-x

ČERNÝ, P. (2008): Právní ochrana před extremismem. Praha: C.H. Beck.

Dohovor o ochrane l'udských práv a základných slobôd (Oznámenie č. 209/1992 Zb.)

GAHÉR, F. (2015a): Interpretácia v práve I., Filozofia, 70 (8), 647 - 658. Dostupné online: $<$ http://www.klemens.sav.sk/fiusav/doc/filozofia/2015/8/647-658.pdf >.

GAHÉR, F. (2015b): Interpretácia v práve II., Filozofia, 70 (10), 789 - 799. Dostupné online: $<$ http://www.klemens.sav.sk/fiusav/doc/filozofia/2015/10/789-799.pdf>.

GERLOCH, A. (2013): Teorie práva. Plzeň: Vydavatelství Aleš Čeněk.

'Hate Speech' Explained. A Toolkit. (2015) London: Article 19. Dostupné online: < https://www.article19.org/data/files/medialibrary/38231/'Hate-Speech'-Explained---A-Toolkit-\%282015Edition\%29.pdf>.

Hate Speech (factsheet) (2017): Strasbourg: European Court of Human Rights. Dostupné online: <http://www.echr.coe.int/Documents/FS_Hate_speech_ENG.pdf > [5. 6. 2017]

HEINZE, E. (2016): Hate Speech and Democratic Citizenship. Oxford: Oxford University Press.

HEINZE, E. (2019): What is 'dehumanising' speech? Dostupné online: <https://freespeechdebate.com/discuss/what-is-dehumanising-speech/> [25. 2. 2019]

HERCZEG, J. (2007): Trestné činy z nenávisti. Praha: Aspi.

HRKÚT, J. (2018) Metaestetické riešenie sporu klasifikačného a hodnotiaceho pojmu umenia u Eddyho Zemacha. Filozofia, 73 (5), 378 - 388. Dostupné online: < http://www.klemens.sav.sk/fiusav/doc/filozofia/2018/5/378-388.pdf>.

IVOR, J., ZÁHORA, J., KLIMEK, L. (2013): Trestné právo Európskej únie a jeho vplyv na právny poriadok Slovenskej republiky. Žilina: Eurokódex.

KISKA, R. (2012 - 2013): Hate speech: a comparison between the European Court of Human Rights and the United States Supreme Court jurisprudence. In: Regent University Law Review, 25 (1), 107 - 151. Dostupné online: $<$ https://www.regent.edu/acad/schlaw/student_life/studentorgs/lawreview/docs/issues/v25n1/04Kiskavol.25.1.pdf>. 
KRIVOŠÍK, L. (2019): Uznávaného profesora chcú študenti nechat' vyhodit' z Oxfordu. Dostupné na internete: <https://www.postoj.sk/39477/uznavaneho-profesora-chcu-studenti-nechat-vyhodit-z-oxfordu> [6. 4. 2019].

KUNA, M. (2018): Sloboda prejavu verzus nenávistný prejav. Studia Aloisiana, 9 (2), 43 - 58. Dostupné online: <http://studiaaloisiana.tftu.sk/wp-content/uploads/2018/08/Kuna_2018_2.pdf>.

KUNA, M. (2019): Symbolický politický nenávistný prejav a jeho právna regulácia. Studia Aloisiana, 10 (1), 5 - 24. Dostupné online: $<\mathrm{http}: / /$ studiaaloisiana.tftu.sk/wp-content/uploads/2019/04/Kuna_2019_1.pdf>.

LABUDA, P. (2018): O povahe filozofie z historicko-pragmatistickej perspektívy. Filozofia, 73 (5), 366 - 377. Dostupné online: <http://www.klemens.sav.sk/fiusav/doc/filozofia/2018/5/366-377.pdf>.

MENCEROVÁ, I. a kol. (2015): Trestné právo hmotné. Všeobecná čast'. Šamorín: Heuréka.

REPÍK, B. (2004): Svoboda projevu versus rasismus ve štrasburské judikatuře. Trestněprávni revue, $2,47-52$.

SCRUTON, R. (2007): The Palgrave Macmillan Dictionary of Political Thouhgt. Houndmills: Palgrave Macmillan.

STEUER, M. (2017): Extrémy slobody prejavu a úloha právnej regulácie. Časopis pro právní vědu a praxi 3, 475 - 491. Dostupné online: <https://journals.muni.cz/cpvp/article/view/7099>.

WALDRON, J. (2012): Harm in Hate Speech. Cambridge - MA: Harvard University Press.

WEBER, A. (2009): Manual on Hate Speech. Strasbourg: Council of Europe Publishing. DOI: https://psycnet.apa.org/doi/10.4159/harvard.9780674065086

WILLFLING, P. (2017): Nenávistné prejavy a extrémizmus v rozhodnutiach Európskeho súdu pre l’udské práva. Banská Bystrica: Via iuris. Dostupné online: <https://viaiuris.sk/wp-content/uploads/2018/01/nenavistne-prejavy-a-extremizmus-via-iuris-2017.pdf $>$.

WITTGENSTEIN, L. (1979): Filozofické skúmania. Bratislava: Pravda.

Marian Kuna

Katedra filozofie

Filozofická fakulta

Katolícka univerzita v Ružomberku

Hrabovská cesta 1

03401 Ružomberok

Slovenská republika

e-mail: marian.kuna@ku.sk

ORCID ID: https://orcid.org/0000-0002-6139-2410 